\title{
The Risk of Thrombotic Events in Anetoderma Affecting Young Patients
}

\author{
Anca E. Chiriac' ${ }^{1}$ Mircea Betiu ${ }^{2}$, Cristian Podoleanu ${ }^{3}$, Simona Stolnicu 4,5 \\ 1 Department of Epidemiology, “Grigore T. Popa” University of Medicine and Pharmacy, lași, Romania \\ 2 Department of Dermatology, "Nicolae Testemițanu” State University of Medicine and Pharmaceutics, Chișinău, Republic of Moldova \\ 3 Department of Internal Medicine IV, "George Emil Palade" University of Medicine, Pharmacy, Science and Technology, Târgu Mureș, \\ Romania \\ 4 Department of Pathology, "George Emil Palade" University of Medicine, Pharmacy, Science and Technology, Târgu Mureș, Romania \\ 5 Histopat Invest Laboratory, Târgu Mureș, Romania
}

\section{CORRESPONDENCE}

\section{Cristian Podoleanu}

Str. Gheorghe Marinescu nr. 38

540139 Târgu Mureș, Romania

Tel: +40 265215551

E-mail: podoleanu@me.com

\section{ARTICLE HISTORY}

Received: July 14, 2020

Accepted: November 22, 2020
Anca Chiriac • Str. Hatman Sendrea nr. 2, 700613 lași, Romania. Tel: +40332808703

Mircea Betiu • Bd. Ştefan cel Mare și Sfânt nr. 165 Chişinău, Republic of Moldova. Tel: +37 322205701

Simona Stolnicu • Str. Gheorghe Marinescu nr. 38

540139 Târgu Mures, Romania. Tel: +40 265215551

\section{ABSTRACT}

Anetoderma is a rare skin disease, and its associated risk of thromboembolic events is unknown. Anetoderma is characterized by focal injury of elastic fibers in the dermis, clinically expressed by atrophic skin lesions. We report the case of a young person with anetoderma, drawing attention to the risk of associated thromboembolic peril.

Keywords: anetoderma, thrombotic events, antiphospholipid antibody syndrome, antiphospholipid antibody

\section{INTRODUCTION}

Anetoderma is a rare skin disease, frequently misdiagnosed as atrophic scars after acne or varicella. The diagnosis is based on the clinical characteristics of skin lesions presenting as "atrophic scars" or "footsteps in the snow", completely asymptomatic and disseminated on the trunk and limbs, in variable number. Microscopic examination of the lesion confirms the focal destruction of elastic fibers. Recent observations however, raised the possibility that anetoderma could be a sign of a hypercoagulable state in adults. However, no cases of anetoderma have been previously described in young individuals.

\section{CASE REPORT}

A teenager, a girl aged 15, sought cosmetic treatment for "varicella scars" spread over the trunk, abdomen, and limbs. She was healthy, had no drug treatment, did not recall the onset of the skin lesions, and could not admit having varicella. She was concerned about the esthetic problem of her skin and was otherwise 

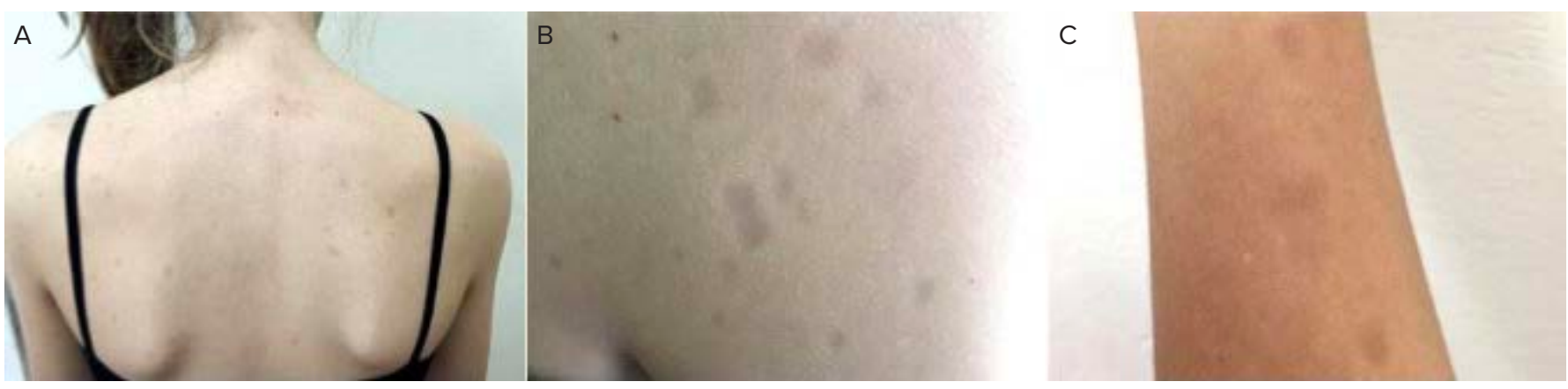

FIGURE 1. Multiple well delineated, flaccid, and herniated lesions involving the trunk (A, B) and limb (C)

completely asymptomatic. She has been treated with peels for her atrophic "scars", without any improvement.

On clinical examination, slightly pigmented, depressed, round and oval, well delineated, flaccid and herniated lesions were observed, in large number and different sizes, on the trunk and limbs, mostly on the superior part of the body. There was no sign of inflammation within and around the lesions (Figure 1).

Meticulous investigations were done, including syphilis, human immunodeficiency virus (HIV), varicella and Borrelia serology, antinuclear antibodies (ANA), lupus anticoagulant, and anti-cardiolipin antibodies, all proving to be negative or within normal range. Endocrine examination excluded autoimmune thyroiditis.

Skin biopsy was performed, and at microscopic examination focal injury (fragmentation) of elastic fibers in the dermis was observed, but no changes within the epidermis were associated, and no inflammatory infiltrate was detected.

Clinical and pathological aspects were in favor of the diagnosis of idiopathic or primary anetoderma. No signs of livedo reticularis or acrocyanosis were noted.

The patient and family members were reassured about the benign nature of the disease, its unknown cause, evolution, and therapeutic options. Laser therapy was recommended in a specialized unit. Close follow-up and regular analysis for a possible thrombotic risk were suggested, although the patient was a child.

Written informed consent for patient information and images to be published was obtained from a legally authorized representative of the patient.

\section{DISCUSSION}

Antiphospholipid antibody syndrome (APLS) is characterized by the presence of an antiphospholipid antibody (APLA) and a thrombotic event (mainly venous thrombosis or miscarriage). ${ }^{1}$
There are two types of APLS: primary APLS, also named idiopathic, in the absence of any identified medical condition; and secondary APLS, in cases of autoimmune disorders, infections, malignant disorders, infections, and drug intake.

In daily practice, APLAs are searched for in case of suspicion of APLS; APLA is a specific antibody anti-cell membrane phospholipid. Three APLAs are currently performed: lupus anticoagulant, anticardiolipin antibody, and anti- $\beta 2$-glycoprotein 1 antibody. ${ }^{2}$ It is of outmost importance to underline that APLAs should be checked twice, at a12-week interval. ${ }^{1}$

Anetoderma is considered one of the skin markers of APLS, ${ }^{2}$ and patients diagnosed with anetoderma should be carefully evaluated and followed-up regardless of the number of lesions or type of anetoderma (primary or secondary). The association of anetoderma and APLAs has been recently attested by revealing their presence in all nine cases of primary anetoderma. ${ }^{3}$

Regarding the classification of anetoderma as primary or secondary, there are different opinions. One view is that primary anetoderma is characterized by lesions localized in areas that appear normal, while secondary anetoderma is associated with previous skin lesions such as acne or varicella. ${ }^{4}$ Based on this concept, primary anetoderma has been diagnosed in patients with comorbidities such as HIV infection or autoimmune disorders (thyroiditis and systemic lupus erythematosus)..$^{5-7}$

Another theory considers anetoderma as primary when it is associated with connective tissue diseases or APLS and anti-thrombin III deficiency, explaining the high risk of thromboembolic events. ${ }^{8}$ In this view, secondary anetoderma has been diagnosed in patients suffering from variable other diseases, without knowing exactly if there is a coincidence or a causative relation.

Secondary anetoderma has been linked to infections: Lyme borreliosis, ${ }^{9}$ syphilis, ${ }^{10}$ HIV infection, leprosy ${ }^{8}$; granuloma annulare, pilomatricoma, Sweet syndrome, 
Stevens-Johnson syndrome, drug intake (penicillamine or penicillin), Wilson's disease; or associated with neoplasia (Reed syndrome, cutaneous lymphomas, xanthogranuloma). ${ }^{8}$ Thus, a long list of diseases diagnosed in patients with anetoderma has been updated.

For some authors, anetoderma should be considered a cutaneous sign of APLS, ${ }^{11}$ and investigation of coagulation anomalies should be a priority, independent the type of anetoderma. $^{12}$

The pathogenesis of anetoderma is still unknown, although many hypotheses have been published. Increased phagocytosis of elastic fibers by macrophages could be another explanation for the destruction of elastic fibers in anetoderma and could support another classification: inflammatory and non-inflammatory anetoderma. ${ }^{8}$

If all patients diagnosed with anetoderma have prothrombotic anomalies, the deterioration of dermal elastic fibers could be explained by focal ischemia. ${ }^{13}$ Other theories are based on the high level of gelatinases in the anetoderma-skin or a similar epitope in the elastic fibers and phospholipids ( $\beta 2$-glycoprotein 1 ), which can explain the occurrence of APLS in anetoderma cases. ${ }^{14}$

\section{CONCLUSION}

Coagulation disorders in patients diagnosed with anetoderma, regardless of their age, should be investigated in dynamics, as a preventive method of severe thromboembolic complications.

\section{CONFLICT OF INTEREST}

Nothing to declare.

\section{REFERENCES}

1. Miyakis S, Lockshin MD, Atsumi T, et al. International consensus statement on an update of the classification criteria for definite antiphospholipid syndrome (APS). J Thromb Haemost. 2006:4:295-306.

2. Thornsberry LA, LoSicco K, English JC 3rd. The skin and hypercoagulable states. J Am Acad Dermatol. 2013:69:450-462.

3. Hodak E, Feureman H, Molad Y, et al. Primary anetoderma: a cutaneous sign of antiphospholipid antibodies. Lupus. 2003:12:564-568.

4. Hodak E, David M. Primary anetoderma and antiphospholipid antibodies review of the literature. Clin Rev Allergy Immunol. 2007;32:162-166.

5. Venhoff $\mathrm{N}$, Miehle N, Juttner $\mathrm{E}$, et al. Clinical images: anetoderma in systemic lupus erythematosus with antiphospholipid antibodies. Arthritis Rheum. 2005;52:2228.

6. Bilen N, Bayamgurler D, Sikar A, et al. Anetoderma associated with antiphospholipid syndrome and systemic lupus erythematosus. Lupus. 2003:12:714-716.

7. Sabio JM, Tercedor J, Massare E, et al. Anetoderma associated with systemic lupus erythematosus and antiphospholipid antibodies. Lupus 2004;13:826-827.

8. Wollina U, Mühle D, Lotti T, et al. Anetoderma Schweninger-Buzzi: Two Case Reports. Open Access Maced J Med Sci. 2019:7:3093-3095.

9. Hofer T, Goldenberger D, Itin PH. Anetoderma and borreliosis: is there a pathogenetic relationship? Eur J Dermatol. 2003;13:399-401.

10. Emer J, Roberts D, Sidhu $H$, et al. Generalized Anetoderma after Intravenous Penicillin Therapy for Secondary Syphilis in an HIV Patient. $J$ Clin Aesthet Dermatol. 2013;6:23-28.

11. Criado PR, Rivitti EA, Vasconcellos C, et al. Manifestações cutâneas das trombofilias. An Bras Dermatol. 2008;83:491-506.

12. Genta MP, Abreu MAMM, Nai GA. Anetoderma: an alert for antiphospholipid antibody syndrome. An Bras Dermatol. 2020;95:123-125.

13. Sparsa A, Piette JC, Wechsler B, et al. Anetoderma and its prothrombotic abnormalities. J Am Acad Dermatol. 2003:49:1008-1012.

14. Romaní J, Pérez F, Llobet M, et al. Anetoderma associated with antiphospholipid antibodies: case report and review of the literature. J Eur Acad Dermatol Venereol. 2001;15:175-178. 